JEMASI: Jurnal Ekonomi Manajemen dan Akuntansi

Vol. 16, No. 1, Januari-Juni 2020

Website: http://ejournal.iba.ac.id/index.php/jemasi

ISSN 1858-2702, e-ISSN 2684-8732

\title{
MODEL PENGUATAN (REINFORCEMENT MODEL'S) UNTUK MEMOTIVASI KELOMPOK USAHA KECIL MIKRO BINAAN BDC SRIWIJAYA PALEMBANG
}

\author{
Ellys Thoyib ${ }^{1}$, R.Y.Effendi ${ }^{2}$ \\ ${ }^{1}$ Universitas IBA, Palembang, Indonesia, ellysthoyib@gmail.com \\ ${ }^{2}$ Universitas IBA, Palembang, Indonesia, effendiry@gmail.com
}

\begin{abstract}
The article "Reinforcement Model's to motivate micro small businesses under the guidance of Sriwijaya BDC" is intended to provide solutions to the Government, stakeholders and Sriwijaya BDC so that the knowledge that has been given in financial management training and business plans, innovation in the taste of kemplang, packaging technology and quality. The study was conducted in November 2019 to January 2020 with 70 respondents, namely participants who attended the training. Data obtained through the distribution of a closed questionnaire, and statements in the design in accordance with the needed information. It is known that the response of thinking, emotions and attitudes of participants to the knowledge gained from the training is a positive response, but the power of motives to direct the motivation to implement that knowledge into their business management is still low. The solution is proposed to provide internal and external reinforcement to the motives so that they have the power to direct motivation so that the participant's behavior is along with the response of thinking, emotions and positive attitudes.
\end{abstract}

Keyword's: Reinforcement models, Motivation, KSM.

\section{PENDAHULUAN}

Usaha kecil mikro adalah usaha rumahan yang dilakukan oleh masyarakat secara kecil-kecilan dengan modal usaha berkisar 200-500 ribu rupiah. Ciri-ciri usaha kecil mikro biasanya proses produksi dilakukan dirumah tempat tinggal sendiri, dimana peralatan dirumah juga berfungsi sebagai alat produksi untuk usaha, pemilik dan karyawannya adalah satu keluarga. Pasar mereka adalah tetangga/keluarga disekitar rumah, produk yang diproduksi produk kearifan lokal, dan keahlian memproduksi diperoleh secara turun temurun atau tradisi/budaya lokal. Kualitas produk juga masih 
rendah hal ini bukan saja dikarenakan bahan baku yang digunakan tetapi juga disebabkan izin dan standar produksi, pengemasan serta sertifikasi produk halal belum dimiliki.

Berbagai cara telah dilakukan oleh Pemerintah melalui program-program Kementerian Pekerjaan Umum dan Perumahan Rakyat (PUPR) untuk meningkatkan kualitas usaha kecil mikro. Mulai dari program P2KP, P2KKP, PNPM Mandiri, PLPBK dan program yang saat ini sedang berjalan adalah program Kota Tanpa Kumuh (KOTAKU). Program Kotaku dan program-program sebelumnya dilaksanakan untuk meningkatkan kualitas kehidupan masyarakat, mulai penataan lingkungan permukiman, infrastruktur kelurahan dan desa, permodalan serta kompetensi SDM khususnya pengusaha kecil mikro. Penataan lingkungan permukiman dan infrastruktur kelurahan dan desa, difokuskan kepada perbaikan jalan-jalan kampung/desa, jembatan, goronggorong dan MCK. Diharapkan dengan lingkungan tertata dan bersih kegiatan produksi usaha kecil mikro lebih bersih dan lancar.

Untuk permodalan, usaha kecil mikro, diberikan pinjaman tanpa agunan dan tanpa bunga secara berkelompok serta dapat dicicil sesuai dengan kemampuan, model ini disebut dengan tanggung renteng. Model ini ternyata tidak terlalu disukai karena apabila salah satu atau lebih dari anggota kelompok macet melakukan pecicilan, maka harus ditanggung oleh anggota yang lain dalam satu kelompok. Belum lagi ada persepsi dari sebagian usaha kecil mikro yang menganggap bahwa pinjaman permodalan tersebut adalah pemberian dari Pemerintah sehingga tidak perlu dikembalikan. Akibat dari sikap dan perilaku ini perputaran dana permodalan yang dikucurkan Pemerintah tidak efektif.

Untuk meningkatkan kompetensi memproduksi produk usaha kecil mikro dan pengelolaan keuangan usaha, Pemerintah memberikan pelatihan vokasi tentang manajemen keuangan dan rencana bisnis, sedangkan untuk proses produksi, pelatihan vokasi dilakukan dengan belajar langsung ke pelaku usaha yang sudah berstandar SNI, berbahan baku halal dan menggunakan kemasan yang hygienis. Para peserta pelatihan ini merupakan kelompok usaha mikro binaan BDC Sriwijaya Palembang. Business development centre (BDC) adalah suatu lembaga yang dibentuk oleh Kementerian PUPR disetiap kabupaten dan kota diseluruh Indonesia. Lembaga ini menjadi pembina/pembimbing dan mitra kerja KSM agar mampu berkembang sebagai pelaku usaha produk-produk unggulan daerah. Di Palembang lembaga ini bernama BDC Sriwijaya. BDC dibentuk sebagai pusat bisnis produk-produk unggulan Sumatera Selatan yaitu pempek, kemplang kerupuk, tekwan, kain jumputan dan tenun songket. Struktur organisasi BDC terdiri dari kelompok komite sebagai pengawas dan manajer bersama karyawan sebagai pengelola. BDC bekerjasama dengan lembaga-lembaga pendidikan untuk melaksanakan kegiatan pelatihan vokasi bagi KSM binaannya, diantaranya bekerjasama dengan Laboratorium Pengembangan Akuntansi dan Manajemen (LPAM) Fakultas Ekonomi Universitas IBA Palembang. Disini LPAM bertindak sebagai provider dalam pelaksanaan kegiatan pelatihan vokasi. 
Pelatihan vokasi tersebut telah dilaksanakan pada tanggal 11 sampai 15 November 2019 dengan tema “ Inovasi Rasa kemplang dan Teknologi Kemasan dan Mutu Produk", kepada 70 orang peserta kelompok swadaya masyarakat (KSM). Kelompok swadaya masyarakat ini adalah para pelaku usaha kecil mikro pempek, kemplang kerupuk dan kue-kue kuliner khas yang ada beberapa kelurahan yang ada di Palembang. Sebelumnya pada tahun 2018 kelompok ini telah mendapatkan pelatihan vokasi manajemen keuangan dan rencana usaha. Kedua pelatihan ini bertujuan untuk memberikan pengetahuan tentang proses produksi, pengemasan dan pengelolaan keuangan usaha yang baik kepada KSM sehingga dapat membangun kebiasaan berproduksi menurut Standart Nasional Indonesia (SNI) dan mengadministrasikan setiap transaksi keuangan usaha. Hal ini sudah menjadi prioritas untuk menjamin kepercayaan kepada konsumen di era globalisasi dan kemajuan tehnologi internet saat ini dan masa yang akan datang.

Setelah usai pelatihan manajemen keuangan dan rencana usaha, setahun kemudian, dilakukan monitoring kembali untuk melihat keberlanjutan pelaksanaan pengetahuan tersebut, hasilnya sangat mengecewakan, KSM tidak memiliki buku pencatatan pengelolaan keuangan usaha sebagaimana telah diajarkan pada pelatihan tersebut, mereka tetap saja pada kebiasaan lama yaitu mencatat melalui ingatan, hanya satu dua orang saja yang melakukan pencatatan transaksi secara tertulis. Begitu pula setelah pelatihan kedua yaitu pelatihan Inovasi rasa kemplang dan pelatihan Teknologi kemasan dan mutu produk, KSM tetap saja masih memproduksi pempek, kemplang dan kerupuk dengan bahan baku ikan, sagu dan proses produksi serta kemasan yang belum terstandar sebagaimana kebiasaan mereka. Sehingga dapat dikatakan bahwa model pelatihan vokasi yang telah dilakukan tidak membuahkan hasil yang diharapkan, tidak ada perubahan perilaku peserta.

Merubah kebiasaan lama KSM kepada kebiasaan baru adalah sesuatu yang tidak mudah, dibutuhkan banyak faktor penguatan yang saling berkoordinasi secara komprehensip agar tujuan Pemerintah untuk mengembangkan usaha mikro kecil dapat membuahkan hasil.

Dari hasil penelitian penulis sebelumnya tentang kemampuan peserta untuk menyimpan dan mengingat kembali pengetahuan manajemen keuangan dan rencana bisnis dalam jawaban pre dan post-test menunjukkan trend positif cukup tinggi yaitu 73\% (Ellys, 2018). Begitu pula respon atau tanggapan berfikir/kognitif peserta, dimana respon ini telah menggambarkan bahwa peserta pelatihan berfikiran positif. Mereka berfikir bahwa pengetahuan ini dapat membantu pengelolaan keuangan dan menyusun rencana usaha, adalah 83\%. (Ellys., 2019) Berikut grafik tentang kemampuan peserta untuk mengingat kembali dan respon berfikir positif terhadap pengetahuan manajemen keuangan dan rencana usaha 


\section{Grafik 1. Kemampuan mengingat kembali dan respon berfikir positif peserta terhadap pengetahuan manajemen keuangan dan rencana usaha.}

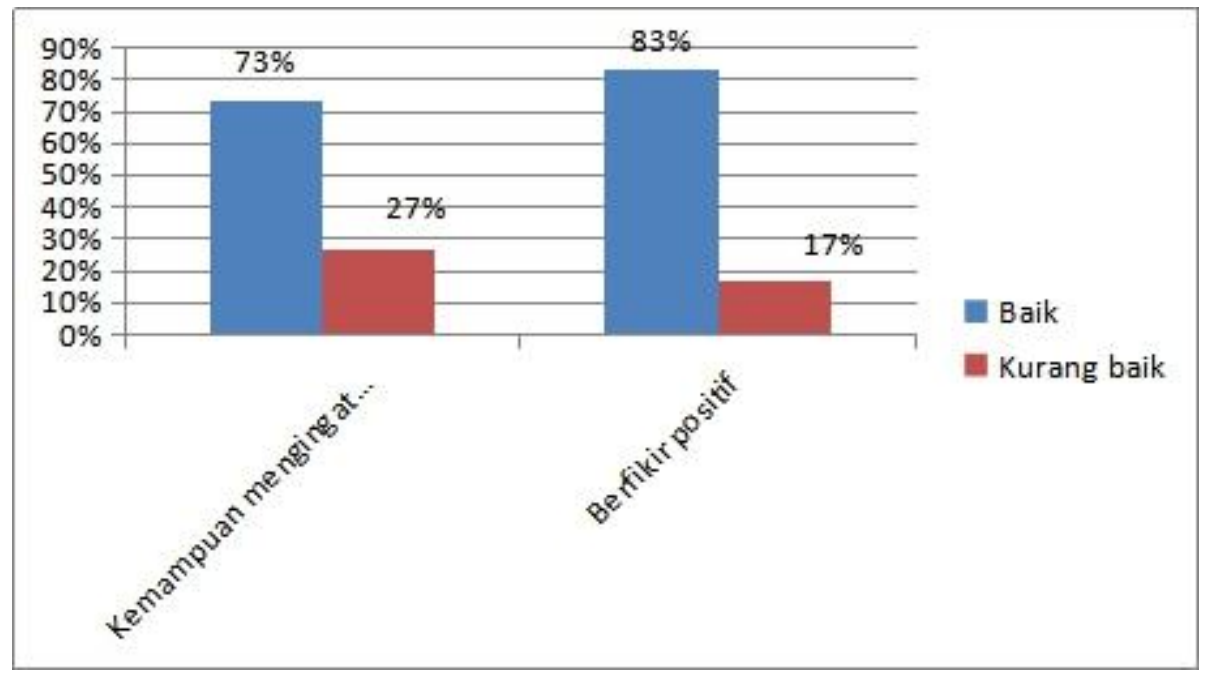

Sumber : (Ellys., 2019)

Kemampuan mengingat kembali dan respon berfikir positif yang baik yaitu $73 \%$ dan $83 \%$, tidak serta merta akan diikuti oleh perilaku positif atau kesediaan mengadopsi dan mengimplementasikan, melakukan pencatatan transaksi keuangan dan menyusun rencana usaha. Sulit melakukan perubahan masih menjadi hambatan yang berat bagi KSM. Fenomena ini terulang kembali setelah KSM mendapat pelatihan Inovasi rasa kemplang dan Tehnologi kemasan dan mutu produk, dimana diharapkan KSM akan melakukan perubahan dari proses produksi tradisional kepada standarisasi proses produksi, inovasi dan mutu produk serta kemasan, namun hal inipun tidak dilakukan. Penulis mencoba kembali menganalisis hasil jawaban pre-test dan post-test peserta pelatihan kedua, yaitu pelatihan Inovasi rasa kemplang, Teknologi kemasan dan mutu produk, untuk mengetahui tentang respon berfikir, respon emosi, respon sikap dan motivasi peserta untuk mengadopsi serta mengimplementasikan pengetahuan tersebut. Penulis melalui beberapa kuisioner tertutup yang diajukan pada saat pre-test dan post-test dengan materi yang dikelompokkan pada 4 kelompok yaitu ;

1. Kemampuan pemahaman materi melalui respon berfikir peserta.

2. Kemampuan pemahaman materi melalui respon emosi peserta.

3. Sikap untuk melakukan perubahan standarisasi proses produksi, kemasan dan mutu produk.

4. Motivasi peserta untuk melakukan inovasi rasa, perubahan kemasan dan mutu produk pempek dan kemplang kerupuk. 


\section{Grafik 2. Respon berfikir, emosi, sikap dan motivasi peserta terhadap pengetahuan Inovasi rasa kemplang dan Teknologi kemasan dan mutu produk}

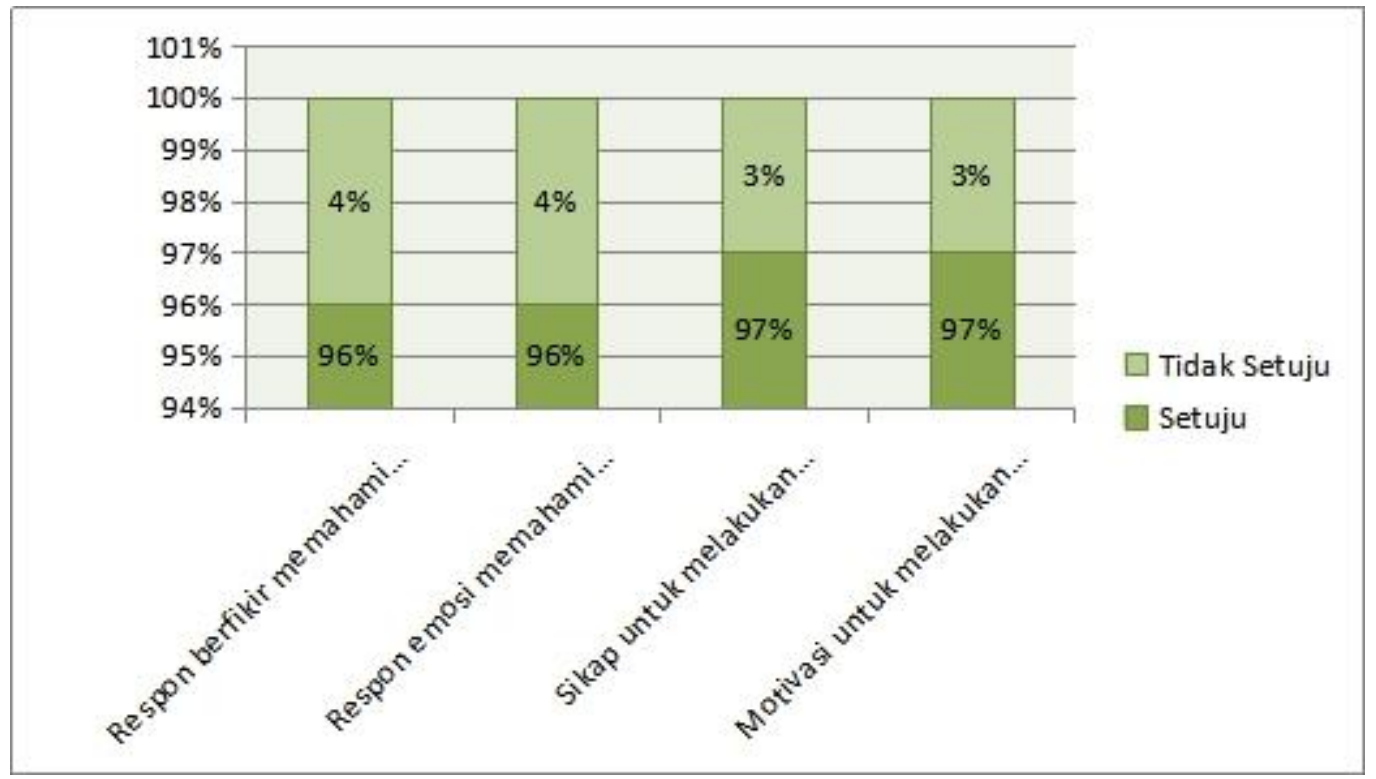

Sumber : Rekapitulasi jawaban pre-post-test, 2019

Dari data-data yang tergambar pada grafik 1 dan 2 menunjukkan bahwa respon psikologis peserta pelatihan terhadap pengetahuan managemen keuangan, rencana usaha, inovasi rasa kemplang, teknologi kemasan dan mutu produk adalah positif dan sangat baik. Mulai dari kemampuan mengingat kembali, respon berfikir, respon emosi, respon sikap dan motivasi untuk melakukan perubahan. Namun ketika pada tahap implementasi dimana mereka harus mengadopsi dan mulai membiasakan diri untuk menerapkan pengetahuan ini kedalam perilaku pengelolaan administrasi keuangan, proses produksi, pengemasan pempek dan kemplang kerupuk, ternyata hanya satu dua orang yang hanya melakukan seadanya. Berbagai alasan mereka kemukakan mengapa mereka belum melaksanakan pengetahuan tersebut. Alasan-alasan tersebut diantaranya; karena usaha mereka masih mikro sekali, dengan modal usaha, kapasitas dan tempat produksi serta pasar yang sangat terbatas sementara untuk standarisasi proses produksi berarti harus semuanya standar, mulai dari bahan baku, tempat dan peralatan, produksi, pengemasan dan pengadministrasian keuangan. Dibutuhkan dana yang cukup besar untuk memenuhinya, sedangkan mereka tidak mampu. Problema ini terus menjadi batu sandungan untuk memajukan UMKM. Dalam kondisi ini penulis mencoba memberikan sumbangan pemikiran dengan menyusun sebuah model penguatan (Reinforcement model's), dengan harapan dapat memberikan solusi bagi pihak-pihak terkait yaitu Pemerintah, swasta (stakeholder's) dan BDC Sriwijaya. 


\section{METODE PENELITIAN}

\section{Methodologi}

Objek yang diteliti KSM pempek dan kerupuk kemplang, berjumlah 70 orang peserta yang telah mengikuti 3 jenis pelatihan vokasional sebagai populasi kemudian seluruh populasi dijadikan responden atau metode sampling jenuh. Waktu penelitian November-Desember 2018 dan November 2019. Tempat penelitian Rizky Kemplang, Aula Universitas IBA, kelurahan Karanganyar, 13,14 dan 15 ilir Palembang.

\section{Desain Penelitian}

Penelitian ini didesain dan dianalisis secara desktiptif kualitatif yaitu mengidentifikasi fenomena psikologis yang berhubungan dengan pemikiran, emosi, sikap, motivasi,dan perilaku peserta setelah mendapatkan pelatihan vokasional Manajemen keuangan dan rencana usaha, Inovasi rasa kemplang, Teknologi kemasan dan mutu produk. Dinamika fenomena psikologis ini akan di dianalisis melalui teori-teori yang relevan untuk disajikan sebagai suatu artikel ilmiah yang layak dipahami dan diketahui oleh publik.

\section{Metode Pengumpulan Data}

Data diperoleh melalui kuisioner pre-test dan post-test berupa pernyataan tertutup kepada peserta untuk mengetahui kemampuan mengingat kembali dan berfikir positif terhadap pengetahuan manajemen keuangan dan rencana usaha. Sedangkan untuk mendapatkan data tentang respon berfikir dan respon emosi terhadap pengetahuan inovasi rasa kemplang dan teknologi kemasan dan mutu produk, juga dalam bentuk pretest dan post-test dimana pernyataan -pernyataan didesain kalimatnya yang dapat menstimulus respon berfikir, emosi, sikap dan motivasi peserta. Untuk mengetahui apakah mereka sudah mengimplementasikan atau belum pengetahuan yang sudah diberikan, penulis melakukan survey ketempat tinggal peserta yaitu di Kelurahan Karanganyar, 13, 14 dan 15 Ilir .

\section{Metode Analisis}

Hasil jawaban KSM yang telah disajikan pada tabel 1 dan 2 akan dianalisis dengan metode deskriptif kualitatif yaitu data kuantitatif yang menunjukkan persentase persetujuan peserta bahwa pengetahuan yang mereka pelajari dalam ketiga jenis pelatihan telah melatih daya ingat, ada tanggapan positif, respon berfikir, respon emosi, respon sikap dan motivasi untuk melakukan perubahan, akan dianalisis dengan teori-teori yang relevan yang berkaitan dengan teori stimulus - respon dan teori-teori penguatan (reinforcement theory) kemudian disusun sebuah model yang sedianya dapat menjadi satu alternatif solusi didalam mengatasi permasalahan KSM yang belum membiasakan untuk mengimplementasikan pengetahuan yang telah mereka dapatkan didalam pelatihan yang bertujuan untuk memberikan pengetahuan tentang standarisasi pengelolaan 
keuangan usaha, proses produksi dan pengemasan produk pempek dan kemplang kerupuk yang mereka produksi.

\section{ANALISIS DAN HASIL PEMBAHASAN}

Pada pelatihan manajemen keuangan dan rencana usaha, dihasilkan $73 \%$ peserta setuju dan mampu mengingat kembali pernyataan-pernyataan sehingga mendapatkan nilai baik setelah post-test untuk kemampuan mengingat materi, ini menunjukkan indikasi bahwa pengetahuan yang di berikan pada pelatihan sudah tersimpan didalam ingatan peserta. Menurut (Peter.C.Olson, 2009), pengetahuan yang direspon oleh indera akan tersimpan dalam ingatan dan akan menjadi pengetahuan, nilai dan kepercayaan seseorang. Selanjutnya proses ini berlangsung secara psikologis pada system kognitif seseorang, sehingga akan menghasilkan pemikiran, emosi, sikap dan motivasi (Thoha, 2016). Pengetahuan yang tersimpan dalam ingatan akan membentuk pola pikir seseorang, apabila ada kesesuaian antara pengetahuan atau stimulus yang baru, maka akan muncul pikiran positif orang tersebut. (Kinichi, 2014), Hal ini ditunjukkan dari nilai jawaban peserta dimana $83 \%$ peserta berfikir positif atau menerima dan percaya tentang pentingnya pengetahuan ini untuk memberikan kepercayaan kepada stakeholder's dan kemajuan usaha mereka.

Pada peserta pelatihan inovasi rasa kemplang dan teknologi kemasan dan mutu produk, respon berfikir positif 96\% artinya peserta mampu memahami materi dan percaya pengetahuan ini sangat penting untuk kemajuan usaha mereka. Keseriusan peserta mendengarkan penjelasan instruktur dan melakukan setiap tahapan proses produksi dengan baik serta mengajukan pertanyaan-pertanyaan yang relevan bila menemukan permasalahan, merupakan bukti bahwa ada respon berfikir positif pada peserta. Respon berfikir merupakan aktifitas psikologis seseorang mulai dari kegiatan untuk memahami, mengevaluasi, berencana, memutuskan dan berfikir. (J \& Jerry, 2014). Selain respon berfikir positif, dapat juga terjadi respon berfikir negatif, dimana tidak ada kesesuaian antara pengetahuan yang baru dengan pengetahuan yang sudah tersimpan dalam ingatan seseorang (Thoha, 2016). Ketidaksesuaian tersebut dapat disebabkan karena seseorang belum pernah mengetahui pengetahuan tersebut, atau karena lupa. Respon emosi juga tampak saat pelatihan, dimana peserta mencoba untuk mengemukakan berbagai kreasi inovasi rasa kemplang dan kemasan.

Respon emosi peserta pada pelatihan ini sangat tinggi yaitu 96\%, hal ini ditunjukkan melalui suasana hati yang bahagia, merasa puas telah memperoleh pengetahuan yang dapat membantu pengembangan usaha mereka. Namun respon emosi juga dapat berupa perasaan ragu dan frustasi (A.Judge, 2015), misalnya ada kegundahan para peserta, dimana mereka merasa tidak mampu untuk memenuhi standarisasi proses produksi karena membutuhkan tempat serta peralatan produksi dengan dana yang cukup besar, sehingga mereka ragu bahkan frustasi apakah mereka bisa melakukannya. Respon 
emosi biasanya durasinya sangat pendek, lebih cepat datang dan lebih cepat pergi. (A.Judge, 2015).

Selanjutnya dikatakan bahwa respon berfikir dan respon emosi yang sama-sama positif akan membentuk sikap yang positif. Sikap sebagai elemen kognitif dapat menjelaskan maksud seseorang untuk berperilaku dengan cara tertentu. Sikap dapat ditunjukkan dengan kata-kata, sikap yang kosisten dengan perilaku bila kata-kata seseorang mengatakan A, maka perilakunya juga akan A, tapi bila kata-katanya A tapi perilakunya $\mathrm{B}$, berarti telah terjadi pertentangan/inkonsistensi (disonansi) antara sikap dan perilaku. Konsistensi dan inkonsistensi antara sikap dan perilaku biasanya disebabkan oleh unsur maksud.

Menurut model perilaku terencana Ajzen (Kinichi, 2014), maksud adalah prediktor atau tujuan yang kuat didalam fikiran dan emosi seseorang apabila melaksanakan perilaku tertentu. Maksud dapat juga disebut sebagai motif yaitu perangsang keinginan (wants) atau daya penggerak kemauan seseorang bekerja/berusaha. Setiap motif mempunyai tujuan tertentu yang ingin dicapai. (S.P.Hasibuan, 2010). Motif akan terus mendesak dan mendorong perilaku seseorang untuk mencapai tujuan. Kekuatan dan arah yang mendorong seseorang untuk berperilaku mencapai tujuan merupakan motivasi seseorang. (A.Judge S. P., 2015). Selanjutnya dikatakan dalam teori Pavlov, dimana Pavlov ingin memahami perilaku yang dikondisikan terhadap seekor anjing yang diberi makan setiap jam 12.00 siang. Dengan membunyikan bel maka makanan akan keluar, sehingga setiap bunyi bel maka seketika itu air liur anjing akan keluar dengan sendirinya. (A.Judge S. P., 2015). Fenomena ini menggambarkan bahwa makanan merupakan motif yang telah merangsang rasa lapar sang anjing sampai mengeluarkan air liur.

Motif ini akan terus mendorong dan memberikan kekuatan atau dengan kata lain memotivasi sang anjing untuk terus mengeluarkan air liur sampai mendapatkan makanan. Begitu juga dengan motif yang mendorong seseorang, dimana seseorang akan terus melakukan sesuatu sampai tujuan tercapai. Runtutan aktifitas psikologis seseorang didalam konsep kognitif merupakan aktifitas stimulus dan respon. Stimulus berupa pengetahuan yang dipelajari peserta pada pelatihan manajemen keuangan dan rencana usaha, inovasi rasa kemplang, teknologi kemasan dan mutu produk. Sedangkan respon merupakan proses berfikir, emosi, sikap dan motivasi serta perilaku peserta. Namun kekuatan rangsangan stimulus yang terjadi pada peserta pelatihan manajemen keuangan, inovasi rasa kemplang dan teknologi kemasan dan mutu produk hanya sebatas pada sikap yang berwujud sebagai motivasi, untuk tindakan mengadopsi dan membiasakan mengimplementasikan pengetahuan tersebut kedalam aktifitas pengelolaan usaha mereka belum terjadi. Disinilah dibutuhkan faktor penguatan (reinforcement factor) agar kekuatan motif tidak melemah atau hilang sama sekali.

Setiap manusia pasti mempunyai motif ketika berperilaku, dibutuhkan penguatan baik internal maupun eksternal. Penguatan internal dimana motif yang ada didalam diri 
dan lingkup organisasi mereka dan dapat diwujudkan dengan semangat/motivasi yang kuat, tindakan terarah dan ketekunan dari diri orang tersebut. (A.Judge S. P., 2015). Sedangkan penguatan eksternal adalah faktor-faktor lingkungan yang dapat memfasilitasi perilaku seseorang untuk mewujudkan motif. Berikut ilustrasi "Model penguatan " (reinforcement model's) untuk memotivasi kelompok usaha kecil mikro binaan BDC Sriwijaya."

\section{Gambar 3. Model penguatan (reinforcement model's) untuk memotivasi kelompok swadaya masyarakat (KSM) binaan BDC Sriwijaya}

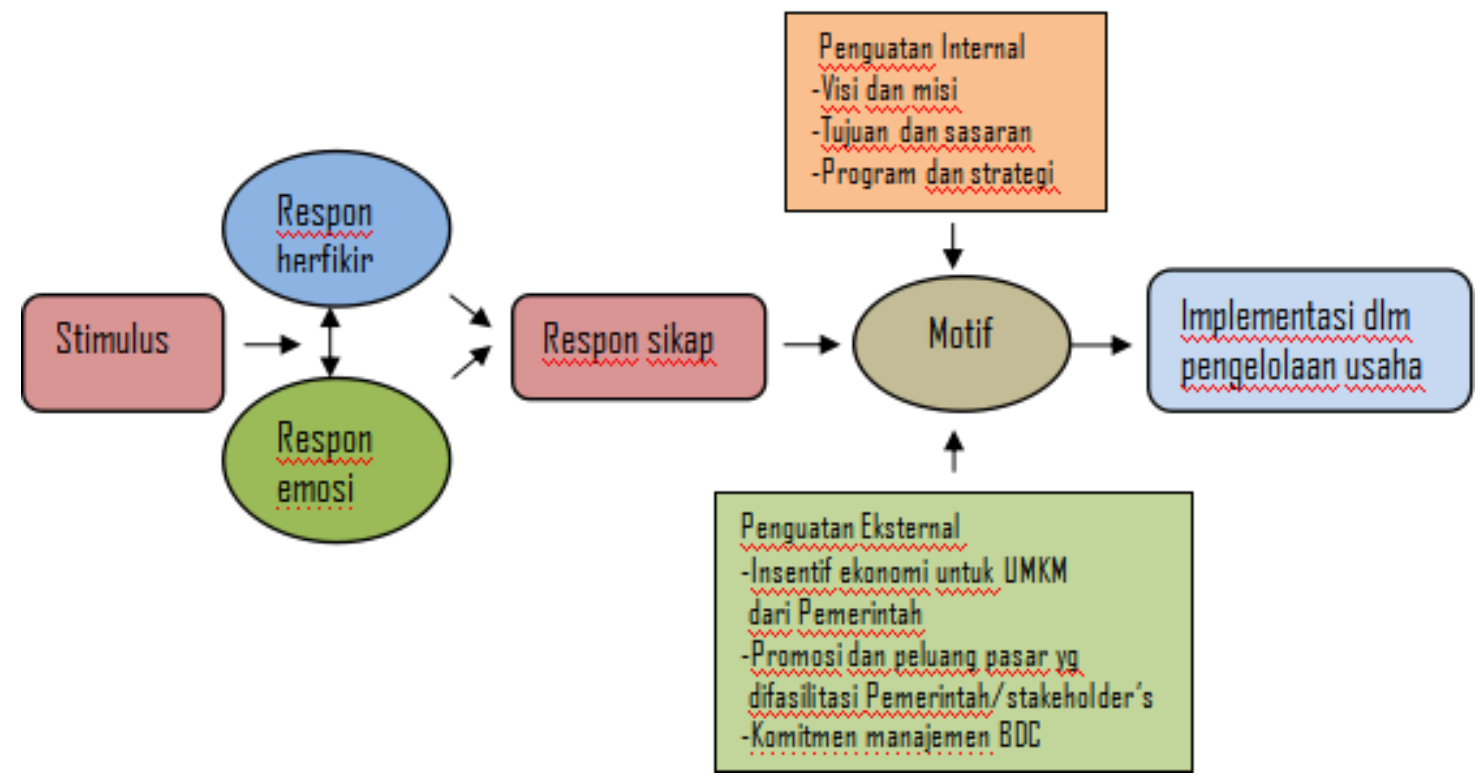

Sumber : Miftah Thoha dan hasil olah penulis, 2020

\section{Analisis}

Model penguatan (reinforcement model's) adalah sebuah acuan untuk memberikan pemahaman dan motivasi kepada kelompok usaha kecil mikro agar memperkuat, mengarahkan dan tekun menjalankan usaha untuk mencapai tujuan yaitu pengembangan usaha pempek dan kemplang kerupuk yang terstandarisasi proses produksi, inovasi, kemasan dan mutu produk serta pengadminitrasian pengelolaan keuangan. Sebagaimana terlihat pada gambar 1. Model ini ditujukan untuk mempertahankan, memperkuat dan mengarahkan motif melalui ketekunan didalam mencapai tujuan mereka dengan diberikan penguatan internal dan eksternal. Penguatan internal adalah penguatan dari dalam internal organisasi, yaitu pengusaha dan proses manajemen usaha. Penguatan internal tersebut ;

1. Visi dapat dikatakan sebagai cita-cita mulia yang harus menjadi roh setiap perilaku orang-orang yang berada dalam suatu organisasi. Mengapa dikatakan sebagai citacita mulia..?, karena apapun yang difikirkan, dirasakan, diinginkan dan dilakukan 
seseorang fokus untuk kebaikan bagi dirinya dan orang lain. Sedangkan harus menjadi roh berarti penggerak perilaku setiap orang dalam organisasi bermuara pada cita-cita mulia. Visi akan mengarahkan motif seseorang untuk melakukan kegiatan yang mengarah kepada apa yang ingin dicapai. Misalnya KSM pempek dan kemplang kerupuk mempunyai visi "Menyediakan aneka pempek dan kemplang kerupuk yang enak dan hygienis".

2. Misi merupakan penjabaran dari visi. Karena visi bersifat umum dan berjangka waktu yang panjang, maka dibutuhkan penjabaran kegiatan berdasarkan tahapan prioritas. Tahapan prioritas tersebut adalah sebagai berikut :

a. KSM melakukan standarisasi, tempat, peralatan, proses produksi, bahan baku dan pembantu serta kemasan pempek dan kemplang kerupuk.

b. Mendaftarkan usaha pempek dan kemplang kerupuk ke Dinas Kesehatan dan BPOM untuk mendapatkan izin PPIRT Dan SNI.

c. Mendaftarkan ke Kementerian Agama untuk mendapatkan label produk halal.

d. Meningkatkan kualitas pempek dan kemplang kerupuk melalui inovasi rasa, bentuk dan kemasan yang diminati masyarakat lokal, nasional dan internasional.

e. Memperluas pasar bukan hanya pasar lokal, tapi juga pasar nasional dan internasional.

f. Standarisasi pengadminstrasian pengelolaan keuangan usaha.

3. Tujuan merupakan titik akhir yang akan dicapai setelah melalui berbagai tahapan misi dengan sumber kekuatan visi yang telah ditetapkan. Misalnya tujuan usaha pempek dan kemplang kerupuk KSM adalah berizin, berstandart SNI, berlebel produk halal dan pasar yang semakin berkembang.

4. Sasaran merupakan potensi pasar yang akan dicapai. Misalnya dapat menguasai $40 \%$ pasar peminat pempek dan kemplang kerupuk dipasar lokal, 20\% pasar nasional dan $10 \%$ pasar internasional.

5. Program merupakan rencana-rencana kegiatan yang dibuat untuk menuju tercapainya sasaran. Misalnya menyusun program untuk melakukan standarisasi proses produksi, mutu produk dan kemasan, pelatihan dan pengembangan sumberdaya manusia, inovasi dan pengembangan produk, program promosi, memasuki pasar-pasar baru (penetrasi pasar), program membangun hubungan relasional dengan pelanggan, pemasaran on-line dan off-line.

6. Strategi merupakan rumusan tentang kebijakan, taktik dan siasat baik dibidang produksi, keuangan, sumberdaya dan pemasaran. Strategi dapat dilakukan dalam 3 tingkatan yaitu strategi di tingkat koorporate, tingkat bisnis, dan tingkat fungsional. (Saefullah, 2014).

a. Strategi di tingkat korporate /strategi utama (main strategy) yaitu strategi yang diputuskan oleh pimpinan organisasi untuk menjamin kelangsungan hidup perusahaan secara menyeluruh. Ada tiga strategi di tingkat korporasi yaitu ; 
- Strategi pertumbuhan yaitu dapat dilakukan dengan membuka cabang-cabang lain untuk produk yang sama. Atau melakukan inovasi produk baru (deferensiasi produk) misalnya bukan saja memproduksi pempek kemplang kerupuk original, tapi juga pempek dan kemplang krupuk kekinian.

- Strategi kestabilan yaitu untuk menjaga stabilitas kepuasan pelanggan dan image merk. Misalnya mempertahankan kualitas produk dan pelayanan perusahaan.

- Strategi penghematan yaitu tetap menjadi efisiensi produksi, pemasaran, sumberdaya dan keuangan.

b. Strategi di tingkat bisnis yaitu strategi yang fokus untuk menjaga harmonisasi dengan pelanggan, pemasok dan antisipasi dengan pesaing, pendatang baru atau perusahaan produk subtitusi. Untuk mempertahankan pelanggan, harus melakukan strategi pemosisian (positioning strategy) yaitu terus meningkatkan image produk dan organisasi melalui keunggulan biaya, inovasi dan deferensiasi produk serta pelayanan.

c. Strategi di tingkat fungsional yaitu organisasi mempunyai fungsi yang sama dengan pesaing didalam memperebutkan pelanggan dan pemasok. Dengan kekuatan strategi pemosisian, organisasi harus mampu mempertahankan bahkan meningkatkan pelanggan dan menjaga hubungan dengan pemasok-pemasok yang baik. Menjadi anggota asosiasi pengusaha pempek dan kemplang kerupuk sangat mendukung perkembangan usaha.

Penguatan eksternal menjadikan motif semakin kuat dan terarah. Penguatan eksternal berupa dukungan dari pihak-pihak lain diluar organisasi, diantaranya Pemerintah melalui dinas-dinas terkait, para pengusaha produk sejenis atau produk subtitusi yang telah berhasil dan BDC sebagai lembaga yang dibentuk Pemerintah untuk membimbing UMKM agar dapat berkembang dengan baik. Penguatan dari Pemerintah dapat berupa insentif ekonomi untuk UMKM, misalnya mempermudah persyaratan perizinan dan mengurangi biaya untuk mendapatkan PPIRT, SNI, sertifikasi produk halal, pinjaman permodalan tanpa bunga dan agunan. Kemudian fasilitas untuk mengikuti kegiatan promosi dan membuka peluang pasar nasional dan internasional, baik kegiatan yang diprakarsai Pemerintah ataupun pihak swasta/asosiasi. Komitmen dan kerja profesional manajemen BDC sangat dibutuhkan oleh KSM, mereka butuh penguatan melalui bimbingan dan fasilitasi yang nyata, misalnya memfasilitasi KSM untuk mendapatkan insentif ekonomi dari Pemerintah atau stakeholder's. Memfasilitasi KSM untuk dapat mengikuti kegiatan promosi dan event-event yang dapat membuka peluang pasar nasional atau internasional. Memfasilitasi KSM mendapatkan perizinan, PPIRT, SNI dan sertifikasi produk halal. Apabila semua elemen penguatan internal dan eksternal berjalan sesuai peran dan fungsinya masing-masing, maka kekuatan motif akan terus konsisten mengarahkan perilaku KSM pada jalur visi,misi, tujuan dan sasaran 
dengan menjalankan program serta strategi yang telah direncanakan dengan bantuan dan difasilitasi Pemerintah, stakeholder's dan BDC Sriwijaya.

\section{KESIMPULAN DAN SARAN}

\section{Kesimpulan}

1. KSM pempek dan kempalng kerupuk binaan BDC Sriwijaya adalah UMKM yang memproduksi produk-produk kearifan lokal, yang sedianya akan dijadikan sebagai produk unggulan daerah Sumatera Selatan. Produk-produk unggulan ini akan distandarisasi kualitas mutu dan kemasannya agar dapat memenuhi standart masyarakat global sehingga mampu bersaing di pasar internasional sehingga semakin variatif produk-produk ekspor Indonesia.

2. Fenomena yang menunjukkan UMKM Indonesia kurang berkembang adalah suatu bukti bahwa motivasi KSM untuk maju masih rendah. Padahal Pemerintah sudah mengeluarkan dana yang cukup besar untuk pembiayaan berbagai pelatihan bagi peningkatan kualitas KSM dan produk KSM.

3. Motivasi KSM yang rendah dapat dikarenakan belum kuat dan belum terarah motif KSM, sehingga respon berfikir, respon emosi dan sikap yang positif tidak mampu memotivasi KSM untuk mengimplementasikan semua pengetahuan yang dipelajari dalam pelatihan manajemen keuangan, inovasi rasa kemplang, teknologi kemasan dan mutu produk kedalam pengelolaan dan manajemen usaha pempek dan kerupuk kemplang mereka.

4. Ada keraguan dan frustasi untuk mengimplentasikan pengetahuan tersebut, ada kegundahan para peserta, dimana mereka merasa tidak mampu untuk memenuhi standarisasi proses produksi karena membutuhkan tempat dan peralatan produksi dengan dana yang cukup besar sedangkan manajemen pemasaran mereka masih tradisional.

5. Penguatan internal dalam kelompok usaha kecil mikro ini belum terorganisir dan terstruktur. Sedangkan penguatan eksternal sudah ada misalnya insentif ekonomi, pelatihan vokasi, namun belum komprehensif. Oleh karena itu penguatan yang terarah dan terintegrasi, akan mampu menguatkan motif memajukan dan mengembangkan usaha pempek dan kemplang kerupuk sebagai produk yang diunggulkan serta dapat bersaing dipasar lokal, nasional maupun internasional. Kekuatan motif yang terarah, terorganisir dan dijalankan dengan kesabaran serta ketekunan pasti akan mampu mencapai tujuan yang dicita-citakan.

\section{Saran-saran}

1. Pempek dan kemplang kerupuk Palembang saat ini sudah sangat terkenal di Indonesia bahkan peminatnya sampai kenegara-negara Asia dan manca-negara. Namun keterkenalan pempek dan kemplang kerupuk, merupakan hasil produksi beberapa UMKM tertentu saja, sementara UMKM pempek dan kemplang kerupuk 
dengan skala mikro kecil tidak tidak mampu bersaing di pasar ini. Pemerintah menginginkan seluruh UMKM yang memproduksi pempek dan kemplang kerupuk di Palembang khususnya dan Sumatera Selatan umumnya dapat berkembang dan bersaing seperti UMKM yang sudah merambah pasar dunia tersebut. Memberikan penguatan kepada KSM tidak cukup dengan memberikan pelatihan manajemen keuangan dan rencana usaha, inovasi rasa kemplang, teknologi kemasan dan mutu produk saja. Pelatihan tentang manajemen organisasi juga sangat penting agar KSM mengetahui dan memahami bagaimana menyusun visi, misi, tujuan, sasaran, program dan strategi untuk mengembangkan usaha.

2. Memotivasi KSM tidak cukup dengan meningkatkan kompetensi pengetahuannya saja, tetapi juga harus diikuti dengan penguatan pemberian insentif ekonomi, kesempatan untuk promosi melalui ajang pameran dan expo sehingga dapat bertemu dengan para buyer's nasional dan internasional.

3. Pemerintah Kota Palembang dapat memprakarsai untuk membangun areal pusat kuliner khas dimana pedagangnya adalah UMKM yang sudah terstandarisasi.

4. Memberikan keyakinan kepada KSM dengan mempermudah mengurus perizinan, seperti izin PPIRT, SNI, BPOM dan sertifikat produk halal.

5. BDC sebagai lembaga yang dibentuk oleh Pemerintah untuk membimbing dan memfasilitasi KSM dengan Pemerintah dan stakeholder's, hendaknya melaksanakan tugasnya dengan profesional sampai KSM betul-betul dapat berkembang sebagaimana yang diinginkan Pemerintah. Hal ini juga merupakan janji Pemerintah untuk mensejahterakan rakyat Indonesia diantaranya dengan cara meningkatkan usaha para pengusaha kecil mikro. Kelompok ini sudah terbukti tangguh menghadapi resesi dan mengatasi pengangguran di Indonesia.

\section{REFERENSI}

A.Judge, S. P. (2015). Perilaku Oganisasi, Edisi 16. Jakarta: Salemba Empat.

A.Judge, S. P. (2015). Perilaku Organisasi. Jakarta: Salemba Empat.

Ellys. (2018). Analisis Perilaku Pengetahuan dalam Ingatan Melalui Jawaban pretest,Post-test dan Monitoring I-II Peserta Pelatihan Vokasional Rencana Usaha dan Manajemen Keuangan KSM Binaan BDC Sriwijaya. Palembang: Jemasi,37.

Ellys., R. (2019). Analisis Kognitif Peserta Pelatihan Vokasional Rencana Usaha dan Manajemen Keuangan KSM Binaan BDC Sriwijaya. Palembang: Jemasi Vol.15 No $1,01$.

J, P. P., \& Jerry, C. (2014). Perilaku Konsumen dan Strategi Pemasaran. Jakarta: Salemba Empat.

Kinichi, V. G. (2014). Perilaku Organisasi. Jakarta: Salemba Empat.

Peter.C.Olson, J. a. (2009). Consumer Behavior. Jakarta: Salemba Empat.

Robert, k., \& Angelo, K. (2014). Perilaku Organisasi. Jakarta: Salemba Empat. 
S.P.Hasibuan, M. (2010). Manajemen Sumberdaya Manusia. Jakarta: Sinar Grafika Offset.

Saefullah, E. T. (2014). Pengantar Manajemen. Jakarta: Kencana.

Thoha, M. (2016). Perilaku Organisasi, Konsep Dasar dan Aplikasinya. Jakarta: PT. Raja Grafindo Persada. 